\title{
FUTURE OF LAW
}

\author{
BY \\ Dr. Ragaie Hussein EL SHETEWI \\ Professor of Private International Law \\ Faculty of Law, Sadat University
}

Why we need a law? What functions does the law have in our localities? As the issue of the definition of law, there is no agreement among scholars as to the functions of law. Jurists have expressed different views about the purpose and function of law. It is well known that law is a dynamic concept, which keeps on changing with time and place. It must change with changes in society. Law, in the modern sense, is considered not as an end in itself but is a means to an end. The end is securing social justice. Almost all theorists agree that law is an instrument of securing justice. As Salmond rightly pointed out, "law is a body of principles recognized and applied by the State in the administration of justice." Even Hobbes and Locke recognised the positive role of law when they said, "the end of law is not to abolish or restrain but to preserve or enlarge freedom and liberty." For the Philosopher Kant, the aim of the law is the adjustment of one's freedom to those of other members of the community. Bentham gave a very practical version of the purpose of the law, which according to him, is the maximization of the happiness of the greatest number of the members of the community.

According to Holland, the function of law is to ensure the well-being of society. Thus it is something more than an institution for the protection of individuals' rights.

Roscoe Pound attributed four major functions of law, namely: (1) maintenance of law and order in society; (2) to maintain status quo in society; (3) to ensure maximum freedom of individuals; and (4) to satisfy the basic needs of the people. He treats law as a species of social engineering.

The Realist view about the purpose and function of law is that for the pursuit of the highest good of the individuals and the state as such a controlling agency.

The object of the law is to ensure justice. Justice may be either distributive or corrective. Distributive justice seeks to ensure a fair distribution of social benefits and burden among the members of the community. Corrective justice, on the other hand, seeks to remedy the wrong. Thus if a person wrongfully takes possession of another's property, the court shall direct the former to restore it to the latter. This is corrective justice. Rule of law is the sine qua non for evenhanded dispensation of justice. It implies that everyone is equal before law and law extends equal protection to everyone; judges should impart justice without fear or favour and like cases should be treated alike. 
It must, however, be stated that justice alone is not the only goal of the law. The notion of law represents a basic conflict between two different needs, namely, the need for uniformity and the need for flexibility. Uniformity is needed to provide certainty and predictability. That is, where laws are fixed and generalized, the citizen can plan his/her activities with a measure of certainty and predict the legal consequence of his/her conducts. This is even more necessary in case of certain laws, notably, the law of contract or property. Uniformity and certainty of rules of law also bring stability and security in the social order.

Today the following are taken as important functions of law :

\section{A) Social control}

members of the society may have different social values, various behaviours and interests. It is important to control those behaviours and to inculcate socially acceptable social norms among the members of the society. There are informal and formal social controls. Law is one of the forms of formal social controls. As to Roscoe Pound, the law is a highly specialized form of social control in a developed politically organized society. Lawrence M. Freedman explains the following two ways in which law plays an important role in social control: first, the law clearly specifies rules and norms that are essential for the society and punishes deviant behaviour. "Secondly, the legal system carries out many rules of social control. Police arrest burglars, prosecutors prosecute them, Courts sentence them, prison guards watch them, and parole broads release them.

\section{B) Dispute settlement}

Disputes are unavoidable in the life of society and it is the role of the law to settle disputes. Thus, disagreements that are justiciable will be resolved by law in court or out of court using alternative dispute settlement mechanisms.

\section{C) Social change}

A number of scholars agree about the role of law in modern society as an instrument to social change. Law enables us to have purposive, planned and directed social change. The flexibility of law provides some measure of discretion in law to make it adaptable to social conditions. If the law is rigid and unalterable, it may not respond to changes spontaneously which may lead to resentment and dissatisfaction among the subjects and may even result in violence or revolution. Therefore, some amount of flexibility is inevitable in law. 


\section{RELATIONSHIP BETWEEN LAW AND STATE}

What relationship do you envisage between law and state?

There are three main legal theories with regard to the relationship between law and state. They are: the state is superior to and creates law; law precedes the state and binds it when it comes into existence; law and the state are the same thing looked at from different points of view.

Austin explains that the state is superior to and creates law when he defines law as the command of the sovereign. According to Austin, there must be a political society of 'considerable' numbers, and a superior in that society who is habitually obeyed by the bulk of the members of that community. Within this community, the superior has a sovereign power to lay down the law. Collectively considered, the sovereign is above the law, but a member of the legislature is individually bound by the law. Do you agree with this proposition? Reason out

The theory of sovereignty has been of service as formal theory, but some writers go farther and seek to justify sovereignty as a moral necessity instead of as a convenient hypothesis. For example, Hegelianism treats the state as a supreme moral end being a value in itself; it is not bound by the rules of ethics that apply to an individual person. This theory 'grants to state absolutism the virtue of moral truth'. 'The state is the divine idea as it exists on earth'. Do you share this idea?

This theory has been carried farther by the Naizi and Fascist conceptions, which regard law as but the will of the Leader. These doctrines treat law as an instrument of executive action, not as a check upon it: the law is a weapon to achieve the ends of state policy, not a chain to hamper the executive.

According to the second theory, the law may bind the State. The sovereign has absolute power over positive law but is bound by jus naturale. Ihering considered that law in the full sense was achieved only when it bound both rulers and ruled. Ihering regards the state as the maker of law and he argues that law is the intelligent policy of power, and it is easier to govern if the state voluntarily submits to the law it has created. Then, Jellinek develops this doctrine into a theory of auto limitation-the State is the creator of law, but voluntarily submits to it.

However, Krabbe and Duguit deny that the State creates law. Once we postulate that law is created by a source other than the State, it is easy to see how the State can be bound. According to Krabbe, the source of law is the subjective sense of right in the community. He asserts that any statute, which is opposed to the majority sense of right, is not law. The legislature, executive, and the judiciary are subordinate instruments through which the community expresses its sense of values. 
How can a sense of right to be effective unless persons are willing to put their wills at the service of the ends they desire?

What is the gist of the third theory on the relationships between law and state?

Kelsen illustrates the third type of theory that law and the state are really the same. The state is only the legal order looked at from another point of view. When we think of the abstract rules, we speak of the law: when we consider the institutions, which create those rules, we speak of the State. However, the practical importance of Philosopher Kelsen's approach is that he emphasizes that law is a more fundamental notion than that of the State. While it is true that law cannot exist without a legal order that order may take forms other than that of the state. Hence, the theory is wider, and therefore more acceptable, than that of Austin. A legal order may be created in the international sphere even though no superstate is set up.

What is the state? The normal marks of a state are a fixed territory, population, and competence to rule which is not derived from another state. Kantorowicz defines the state as a juristic person endowed with the right to impose its will on the inhabitants of a given territory, of which right it cannot by law be deprived without its own consent.

It may be argued that the law is an instrument of the state is created and established along with it. No state has ever been without a system of law, however crude it may have been. In like manner, a system of law has been without a state defining either directly (i.e., through enactments) or indirectly (through recognition) the law is and assuring its validity and guarantying its endowment through the special machinery at the disposal of the state only. That is why the law is generally defined as a set of general statements aimed at regulating choices in possible human behaviour that is defined or recognized, published and sanctioned warded by the state.

The definition of law in terms of the State possesses some advantages. It gives a clear-cut and simple test. It supplies an easy manner to show a conflict between various juridical orders for example between Church and State. If only the State can provide positive law, then the Church can have only such legal rules the state grants it. It gives an easy answer to the problem of the validity of the law, since the law is valid for the simple reason that it has been laid down by the sovereign. It is easy to mark the moment when primitive rules become law, for we have only to ask whether there is a determinate sovereign body that has issued a command.

Law, like war, appears to be an inescapable fact of the human condition. But what is its future? The law is, of course, is a constant state of flux. This is nicely expressed by the illustrious American Supreme Court Justice Benjamin Cardozo: Existing rules and principles can give us our present location, our bearings, our latitude and longitude. The inn that shelters us for the night is not 
the journey's end. The law, like the traveller, must be ready for tomorrow. It must have a principle of growth.

In a rapidly changing world, growth and adaptation are more pressing than ever if the law is to respond adequately to the new threats as well as novel challenges it faces. The law's character has unquestionably undergone profound transformations in the last 50 years, yet its future is contentious. Some argue that the law is in its death throes, while others postulate a contrary prognosis that discerns numerous signs of law's enduring strength. Which is it? Curiously, there is some truth in both standpoints. On the one hand, though reports of the death of law have been exaggerated, there is ample evidence of the infirmity of many advanced legal systems. Symptoms include the privatization of law...settlement of cases, plea-bargaining, ADR, the spectacular rise of regulatory agencies with wide discretionary powers, and the decline of the rule of law in several countries. On the other hand, there has been a revolution in the role of law that suggests it is both resilient and robust. This transformation includes the extension of the law's tentacles into the private domain in pursuit of efficiency, social justice, or other political goals; the globalization of law and its internationalization through the United Nations, regional organizations, and the European Union; and the massive impact of technology on the law.

We are trying, here, to uncover some of the major shifts in modern society and the formidable challenges they pose to the law;

\section{Law and Change:}

Various attempts have been made to chart the course of legal development. Legal historians have sought to identify the central features in the evolution of law, and, hence, to situate different societies along this continuum. In the late 19th century, the eminent scholar Sir Henry Maine contended that law and society had previously progressed 'from status to contract'. In other words, in the ancient world individuals were closely bound by status to traditional groups, whereas in modern societies individuals are regarded as autonomous beings, they are free to enter into contracts and form associations with whomever they choose. But this transition may have reversed. In many instances, freedom of contract is more apparent than real. For example, what choice does the consumer have when faced with a standard-form contract (or contract of adhesion) for telecommunications, electricity, or other utilities? And where is the employee who, when offered a job and presented with a standard-form contract by his multinational employee, would attempt to renegotiate the terms? It is true that many advanced legal systems seek to improve the bargaining position of the individual through various forms of consumer protection legislation.

The growth of legal systems also exercised the minds of social theorists. The ideas of Max Weber have exerted a powerful influence on thinking about law and its development : 
* First, he developed a typology of law based on the different categories of legal thought. At its heart is the idea of "rationality ». He distinguishes between « formal » systems and "substantive » systems. The core of this distinction is the extent to which a system is "internally self-sufficient», the rules and procedures required for decision-making are available within the system.

* Second, he draws a distinction between « rational» and « irrational » systems. This describes the manner in which the legal rules and procedures are applied. The highest stage of rationality is reached when all legal propositions constitute a logically clear, internally consistent system of rules under which every conceivable fact or situation is included. Weber gives as an example of a formally legal irrational system the phenomenon of trial by ordeal where guilt is determined by an appeal to some supernatural force. An example of substantive legal irrationality is where a judge decides a case on the basis of his personal opinion without any reference to rules. A decision of a judge is substantively rational, according to Weber, when he refers not to rules but moral principles or concepts of justice.

* Third, where a judge defers to a body of doctrine consisting of legal rules and principles, the system constitutes one of formal logical legal rationality. It is towards this ideal type that Weber's theory of legal evolution progresses. In many societies, however, Weber's model of a rational, comprehensive, and the coherent legal system is undermined by the rapid rise in administrative control. Contemporary societies manifest an enormous expansion in the jurisdiction of administrative agencies. These bodies, normally creatures of statute, are vested with extensive discretionary powers. In some cases, their decisions are explicitly exempted from judicial oversight. Discretionary regulation resembles Weber's notion of substantive legal rationality, while the ideology of the rule of law represents formal legal rationality.

In several European countries, for example, the privatization of formerly nationalized industries (such as utilities and telecommunications) has spawned a host of regulatory agencies with powers to investigate, make rules, and impose penalties. The ordinary Courts may be marginalized, and hence the role of law itself becomes distorted. This development represents a threat to the authority and courts. Moreover, the enlargement of discretionary powers undermines the rule of law's insistence on the observance of clear rules that specify individual rights and duties.

\section{Disappearing Law?}

Among the more radical theories of legal development is the Marxist idea that law is ultimately doomed to disappear entirely. This prediction is grounded in the idea of historicism: social evolution is explained in terms of inexorable historical forces. Karl Marx and Frederick Engels propounded the theory of 
« dialectical materialism » which explains the unfolding of history in terms of the development of a thesis, it's opposite (or antithesis) and, out of the ensuing conflict, its resolution in a synthesis.

Marx argued that each period of economic development has a corresponding class system. During the period of hand-mill production, for instance, the feudal system of classes existed. When steam-mill production developed, capitalism replaced feudalism. Classes are determined by the means of production, and therefore an individual's class is dependent on his relation to the means of production. Marx's « historical materialism » is based on the fact that the means of production are materially determined; it is dialectical, in part, because he sees an inevitable conflict between those two hostile classes. A revolution would eventually occur because the bourgeois mode of production based on individual ownership and unplanned competition, stands in opposition to the increasingly non-individualistic, social character of labour productivity in the factory.

The proletariat would, he predicted, seize the means of production and establish a «dictatorship of the proletariat» which would, in time, be replaced by a classless, communist society in which law would eventually "wither away ». Since the law is a vehicle of class oppression, it is superfluous in a classless society. This is the spirit of the argument first implied by Marx in his early writings and restated by Lenin. In its more sophisticated version the thesis claims that, following the proletarian revolution, the bourgeois state would be swept aside and replaced by the dictatorship of the proletariat. Society, after reactionary resistance has been defeated, would have no further need for law or state: they would «wither away». But this cheerful prognosis is based on a rather crude equation of law with the coercive suppression of the proletariat. It disregards the fact not only that a considerable body of law serves other functions, but that, even, a communist society requires laws to plan and regulate its economy.

Whatever theory is adopted to explain the manner and form of legal change, it is impossible to deny that the future of law is beset with a host of thorny challenges. Where might the greatest difficulties lie?

\section{Internal Challenges :}

In addition to the problem of bureaucratic regulation and the often unbridled discretion it generates (discussed above), there are a number of intractable questions mentioned above and need to be confronted by legal systems everywhere.

Among the most conspicuous is the so-called «war on terrorism ». It requires little perception to realize that in the space of less than a decade many legal systems are faced with a variety of problems that test the values that lie at their heart. How can free societies reconcile a commitment to liberty with the necessity to confront threats to undermine that very foundation? Absolute 
security is plainly unattainable, but even moderate protection against « terrorism » comes at a price. And no airline passenger can be unaware of the cost in respect of the delays and inconvenience that today's security checks inevitably entail.

Nevertheless, although terrorism, hijacking, and crimes, in general, can never be entirely prevented, modern technology does offer extraordinarily successful tools to deter and apprehend offenders. At the most common and public places, closed-circuit television (CCTV) cameras, for instance, are able to monitor unlawful activities, such recordings supplying prosecutors with powerful evidence in Court against the villains. To what extent should the law tolerate this kind of surveillance? The following example demonstrates the difficulty and the unavoidable "balancing » between competing rights that is a conspicuous characteristic of modern law. I like my car. It's nothing special : but its black metallic body colour induces in me a pleasing sensation. A few days ago, as I was about to unlock the door, I noticed a deep scratch that stretched along the side of the car. A key or perhaps a screwdriver had been dragged over its metallic surface. A similar wound had been inflicted on the bonnet. I was furious. Not unlike a character in a movie, I scoured the vicinity in the vain hope of some sign of the vandal, my face suitably arranged in an expression of ferocious indignation. But the miscreant was long gone. The offence had been committed, I presumed, during the night. I was left to my curses. The car was parked in a well-lit area, but this was plainly no deterrent. Why, I instantly lamented, was there no CCTV camera nearby to record the villain's identity? I wanted him caught and punished. A trivial instance of criminal damage, perhaps, but it would be ingenuous not to think that most people would support measures that might successfully prevent crime and, especially since 11 September 2001, acts of terrorism.

Surely, a terrorist, no less than the delinquent who damaged my car, would be failed were a CCTV cameras police instaled in the streets of many cities to record every move?

Law-abiding citizens must feel safer in the knowledge that this surveillance is taking place. And why not? Public opinions confirm their wide support. Who but the robber, killer, or bomber has anything to fear from the monitoring of his or her activities in public places? Nor should it stop there. Advances in technology render the tracking of an individual's financial transactions and email communications very simple. The introduction of «smart» ID cards, the use of biometrics, and electronic road pricing represent major developments in methods of surveillance. Only the malevolent could legitimately object to these effective methods of crime control. Would that this comforting view were true. We cannot afford to pussyfoot with terrorists, but how far should we be willing to trade our freedom for security ? In the immediate aftermath of the events of 11 September 2001, politicians, especially in the United States, have understandably sought to enhance the powers of the state to detain suspects for 
interrogation, intercept communications, and monitor the activities of those who might be engaged in terrorism. The law faces formidable difficulties here. Draconian powers are probably unavoidable during times of war: arbitrary powers of arrest and detention, imprisonment without trial, secret trials...etc. How long can a free society tolerate these infringements of liberty? What lasting damage may be inflicted on the rule of law and individual rights? Can the law continue to protect citizens or will citizens need protection from the law? Are the courts able to act as a bulwark against these attacks on freedom?

A vivid example of a society that attempted a comprehensive assault on "terrorism " is apartheid South Africa. Heavy-handed laws made substantial legislative inroads into the jurisdiction of the courts in the field of civil liberties. The removal of the authority of the judiciary to question the exercise of executive power under a wide range of circumstances considerably attenuated the authority of judges. The ever-increasing sphere of unchecked executive discretion in matters of fundamental liberty such as detention, banning, deportation, and censorship reduced the members of the judiciary to impotent spectators of administrative action. This was a strange distortion of their calling. Moreover, even where a courageous judge was able to interpret the law in favour of liberty, he was, in practice, likely to have his efforts frustrated by legislation to nullify its effect.

The eminent writer Philip Bobbitt in his book « Terror and Consent » wrote that: «We need not sacrifice our constitutional freedoms to win the wars on Terror. Indeed ... twenty-first-century terrorism poses a danger to that freedom. Claims that the U.S. Constitution doesn't apply abroad, or that habeas corpus is a quaint irrelevance, or that persons can be held incommunicado indefinitely, are ones with which I have little sympathy. But neither do I believe that there is a Godgiven right to not be burdened with carrying an identity card, or to not disclose to the government information we have gladly given to private corporations or that they have collected with our consent $»$.

A less flagrant engine of change is the internationalization or globalization of law. The world has witnessed an escalation in the influence and importance of international (the United Nations) or regional organizations (such as the European Union). These sources of law reduce the authority of domestic law. Some of these problems were touched upon there. They are both substantive and procedural and include several quandaries concerning the criminal justice system. What is the future of the criminal trial in the face of complex commercial offences, often involving sophisticated know-how? Is the jury trial appropriate in these circumstances, or at all? Is the civil law inquisitorial system preferable to the common law adversarial approach ? In many jurisdictions, access to the law is patchy. The poor are not always provided with adequate access to the Courts and other institutions of dispute resolution. No less difficult issues surround private law. For example, many legal systems wrestle with the 
difficult question of compensation for personal injuries, and the effect of insurance on the award of damages.

\section{Limits of Law :}

While the law on its own can never transform, or indeed conserve, the social order and its values, it has the capacity to influence and shape attitudes. Efforts to achieve social justice through law have not been an unqualified success. Statutes outlawing racial discrimination, for example, represent only a modest advance in the cause of equality. While little can be accomplished without legal intervention, the limits of law need to be acknowledged.

There is a growing tendency to legalize moral and social problems, and even to assume that the values underpinning democratic Western legal systems, and their institutions, can be fruitfully exported or transplanted to less developed countries. This may be a Utopian view. Equally sanguine may be the proposition that economic development necessarily presages respect for human rights, as is frequently contended in the case of China. Modern governments adopt highly ambitious legislative programmes that frequently verge upon social engineering. To what extent can legislation genuinely improve society, combat discrimination and injustice? Or are courts more appropriate vehicles for social change? Where, as in the United States, a vigorous Supreme Court has the power to declare laws unconstitutional, the legislature has no choice but to fall in line, as it did following the case of Brown Vs. Board of Education of Topeka in 1954. A unanimous court declared the establishment of separate public schools for black and white students « naturally unequal». This decision opened the doors to integration and the birth of the "Civil Rights Movement ». Though discrimination will always exist, few would deny that the case changed the law and society for the better.

Without effective enforcement, laws cannot fulfil their noble aspirations. Legislation prohibiting animal cruelty is a case in point. Vivisection, battery farming, the fur trade, hunting, trapping, circuses, zoos, and rodeos are merely some of the practices, apart from the direct intentional infliction of pain

on an animal, that causes misery and suffering to millions of creatures around the world every day. Anti-cruelty statutes have been enacted in many jurisdictions, yet in the absence of rigorous enforcement, these laws constitute mostly empty promises. And enforcement is a major obstacle: detection is largely dependent on inspectors who lack the power of arrest, prosecutors who rarely regard animal cruelty cases as a high priority, and judges who rarely impose adequate punishment, not that the statutory penalty is itself sufficiently stringent.

In an increasingly anxious world, there is an understandable tendency to look to the law to resolve the various threats to our future. In recent years, the dangers of pollution, depletion of the ozone layer, global warming, and other threats to 
the survival of any kind of animals, marine, bird, and plant life have assumed a higher profile. A growing number of states have introduced legislation to attempt to limit or control the destruction of the planet. The law, however, often proves to be a rather blunt and powerful instrument. For example, in the case of the criminal liability of a company for pollution, a conviction depends on proof that those who control the company had the requisite knowledge or intention. This is very difficult to prove. And even where these acts are strict liability offences, the fines imposed by Courts have a limited effect. It may be that the numerous international treaties, conventions, and declarations on almost every aspect of environmental protection are likely to be more effective, though, as with the law, the predictable stumbling block is effective enforcement.

\section{Law and Injustice :}

The law may, of course, be the source of injustice. As we mentioned above apartheid was a creature of the law. And the same can be said of the atrocities of the Third Reich. And sometimes Courts are guilty of injustice. The infamous Dreyfus affair in France is a striking example of the conviction and punishment of an innocent person as a result of a combination of incompetence and antiSemitism. Though Dreyfus was eventually exonerated, the case demonstrates how even judges may be susceptible to bigotry and prejudice.

The American Supreme Court has not been immune to unjust decisions. In one of its most notorious cases, it decided against David Scott, a slave who in 1847 applied to a court to obtain his freedom. The judges ruled that no person of African origin could ever become a citizen of the United States, and Scott, therefore, had no right to bring his case before the Court. It also held that the government lacked the power to prohibit slavery.

No less dishonourable than the judgment in Plessy Vs. Ferguson in 1896 which upheld the constitutionality of racial segregation in public facilities under the "separate but equal" doctrine.

In 1991 in Los Angeles the case of Rodney King sparked riots after the acquittal of police officers who had struck him up to fifty-six times with metal batons and shot him. A number of bystanders witnessed the beating and one of them videotaped the incident. King suffered a fractured skull and nerve damage to his face. Though some of the officers were subsequently convicted by a federal court on charges of violating King's constitutional rights and imprisoned, none of the prosecutions alleged racial motivation. The policeman shooting of black suspects and the failure to prosecute the alleged offenders remain a highly strange issue in the United States.

It is not surprising that miscarriages of justice occur. Courts are not infallible, and there is always the possibility of errors, false evidence ....etc, that can lead to an innocent condemnation. 


\section{Technological Challenges :}

There is nothing new about the law's struggle to keep abreast with technology. Yet the last 20 years have witnessed an unprecedented transformation of the contest. Digital disquiet easily spawns alarm and anxiety. The emergence of information technology, to select only one obvious instance, poses enormous challenges to the law. Attempts legally to control the Internet, its operation or content, have been notoriously unsuccessful. Indeed, its very anarchy and resistance to regulation is, in the minds of many, its strength and attraction. But is cyberspace beyond regulation? The distinguished legal academic author Lawrence Lessig has persuasively argued that it is susceptible to control, not necessarily by law, but through its essential make-up, its 'code': software and hardware that constitute cyberspace. That code, he suggests, can either produce a place where freedom prevails or one of oppressive control. Indeed, commercial considerations increasingly render cyberspace decidedly amenable to regulation; it has become a place in which conduct is more strongly controlled than in real space. In the end, he maintains, it is a matter for us to determine; the choice is one of architecture: what sort of code should govern cyberspace, and who will control it? And in this respect, the central legal issue is code. We need to choose the values and principles which should animate that code.

Information is no longer merely power. It is big business. In recent years, the fastest-growing component of international trade is the service sector. It accounts for more than one, third of world trade, and continues to expand. It is a commonplace to identify, as a central feature of modern industrialized societies, their dependence on the storage of information. The use of computers facilitates, of course, considerably greater efficiency and in the collection, storage, retrieval, and transfer of information.

The daily functions of the State, as well as private bodies, require a continual supply of data about individuals in order to administer effectively the numerous services that are integral to contemporary life and the expectations of citizens. Thus, to mention only the most conspicuous examples, the provision of health care, social security, and the prevention and detection of crime by the law enforcement authorities assume the accessibility of a vast quantity of such data, and, hence, a willingness of the public to furnish them. Equally in the private, the provision of credit, insurance, and employment generate an almost insatiable hunger for information.

\section{Threats to Individual Privacy :}

The future is unlikely to witness an escalation of our privacy. Can the law curb the apparently relentless slide towards an Orwellian nightmare? "Low-tech" 
collection of transactional data in both the public and private sector has become commonplace.

In addition to the routine surveillance by CCTV in public places, the monitoring of mobile telephones, the workplace, vehicles, electronic communications, and online activity is increasingly taken for granted in most advanced societies. The escalating use of surveillance in the workplace, for example, is changing not only the character of that environment but also the very nature of what we do and how we do it. The knowledge that our activities are, or even maybe, monitored, undermines our psychological and emotional autonomy. Indeed, the slide towards electronic supervision may fundamentally alter our relationships and our identity. In such a world, employees are arguably less likely to execute their duties effectively. If that occurs, the snooping employer will, in the end, secure the precise opposite of what he hopes to achieve.

The privacy prognosis is not encouraging, the future promises more sophisticated and alarming intrusions into our private lives, including the greater use of biometrics, and sense-enhanced searches such as satellite monitoring, penetrating walls and clothing, and "smart" devices (minuscule wireless microelectromechanical sensors (MEMS) that can detect twenty (20) movements. New specialist companies display the sophisticated listening equipment and digital tracking device which discover everything from light to vibrations).

As cyberspace becomes an increasingly perilous domain, we learn daily of new, alarming assaults on its citizens. This slide towards pervasive surveillance coincides with the mounting fears, expressed well before September 11, 2001, about the disturbing capacity of the new technology to undermine our liberty. Reports of the fragility of privacy have, of course, been sounded for at least a century. But in the last decade, they have assumed a more urgent form. And here lies a paradox. On the one hand, recent advances in the power of computers have been decried as the enemy of whatever vestiges of our privacy still survive. On the other hand, the Internet is acclaimed as a Utopia. When (clichés) compete, it is imprudent to expect sensible resolutions of the problems they embody, but between these two exaggerated claims, something resembling the truth probably resides.

In respect of the future of privacy, at least, there can be little doubt that the legal questions are changing before our eyes. And if, in the flat-footed domain of atoms, we have achieved only limited success in protecting individuals against the depredations of surveillance, how much better the prospects in our brave new binary world? When our security is under siege, so - inevitably - is our liberty.

A world in which our every movement is observed erodes the very freedom this snooping is often calculated to protect. Naturally, we need to ensure that the social costs of the means employed to enhance security do not outweigh the benefits. Thus, one unsurprising consequence of the installation of CCTV in car parks, shopping malls, airports, and other public places is the displacement of 
crime; offenders simply go somewhere else. And, apart from the doors this intrusion opens to totalitarianism, a surveillance society can easily generate a climate of mistrust and suspicion, a reduction in the respect for law and those who enforce it, and intensification of prosecution of offences that are susceptible to easy detection and proof.

Though data protection legislation has been enacted in more than thirty (30) jurisdictions, its scope is limited. At its core is the simple proposition that data relating to an identifiable individual should not be collected in the absence of a genuine purpose and the consent of the individual concerned. At a slightly higher level of abstraction, it encapsulates the principle of what the German Constitutional Court has called "informational self-determination", a postulate that expresses a fundamentally democratic ideal. But the enactment of data protection legislation is driven only partly by altruism. The new information technology disintegrates national borders; international traffic in personal data is a routine feature of commercial life. The protection afforded to personal data in Country (A) is, in a digital world, rendered nugatory when it is retrieved on a computer in Country (B) in which there are no controls over its use. Hence, States with data protection laws frequently proscribe the transfer of data to countries that lack them. Indeed, the European Union has in one of its several directives explicitly sought to annihilate these «data havens ». Without data protection legislation, countries risk being shut out of the rapidly expanding information business.

At the heart of these laws are two central canons of fair information practice that speak for themselves: the "use limitation» and "purpose specification» principles. They require renovation where they already exist and urgent adoption where they do not. They may, moreover, be able to provide complementary safeguards for individual privacy in cyberspace.

The future of the right to privacy depends in large part on the ability of the law to formulate an adequately clear definition of the concept itself. This is not only a consequence of the inherent vagueness of the notion of privacy but also because the "right of privacy " has conspicuously failed to provide adequate support to the private realm when it is intruded upon by competing rights and interests, especially freedom of expression. In our burgeoning information age, the vulnerability of privacy is likely to intensify unless this central democratic value is translated into simple language that is capable of effective regulation.

Other developments have comprehensively altered fundamental features of the legal landscape. The law has been profoundly affected and challenged by numerous other advances in technology. Computer fraud, identity theft, and other « cybercrimes », and the pirating of digital music, are touched on below. Developments in biotechnology such as cloning, stem cell research, and genetic engineering provoke thorny ethical questions and confront traditional legal 
concepts. Proposals to introduce identity cards and biometrics have attracted strong objections in several jurisdictions.

The nature of criminal trials has been transformed by the use of both DNA and CCTV evidence. The use of DNA evidence has become a routine feature of a criminal investigation in many countries.

Maintaining security already appears to be alive and well in several countries. Britain, for example, boasts more than four (4) million CCTV cameras in public places: roughly one for every 14 inhabitants. It also possesses the world's largest DNA database, comprising some 3.6 million DNA samples. The temptation to install CCTV cameras by both the public and private sector is not easy to resist. Data protection law ostensibly controls its use, but such regulation has not proved especially effective. A radical solution, adopted in Denmark, is to prohibit their use, subject to certain exceptions such as petrol stations. The law in Sweden, France, and Holland is more stringent than in the United Kingdom. They adopt a licensing system, and the law requires that warning signs be placed on the periphery of the zone monitored. German law has a similar requirement. ID cards of various kinds are widespread throughout the world, though fairly rare in common law jurisdictions. The rise in international terrorism has fuelled the demand for their introduction in several countries. But their capacity to merge personal information from numerous sources poses threats to individual privacy.

\section{The dark side of Biometrics}

Biometrics is one of the most serious among the many technologies of surveillance that are threatening the freedom of individuals and of societies.

In one possible future, biometrics will fall into ill-repute in relatively free countries. But in several countries, biometrics will be successfully imposed on the population, resulting in freedoms being reduced even further. Biometrics providers will flourish by selling their technology to repressive governments, and achieve footholds in relatively free countries by looking for soft targets, starting in some cases with animals, and in others with captive populations like the frail aged, prisoners, employees, insurance consumers, and welfare recipients. All relatively free countries will become more repressive. Public confidence in corporations and government agencies will spiral much lower. This scenario leads away from freedoms, and towards repression of the individual to powerful organizations.

The other alternative is that societies appreciate the seriousness of the threats, and impose substantial constraints on technologies and their use. This demands commitment by the public, and courage by elected representatives, who must resist pressure from large corporations, and from the national security and law enforcement apparatus that invokes such bogeymen as terrorism, illegal immigration, and national law and order as justifications for the implementation 
of repressive technologies. This scenario embodies the scope for achieving balance among the needs of individuals and society as a whole.

In order to counter the threat of terrorism, the future will unquestionably witness increased use of biometrics. Biometrics includes, in particular, a number of measures of human physiography such as fingerprints, aspects of the eye iris, ear lobes, DNA, and descriptions used in passports, such as height, weight, the colour of skin, hair, and eyes, visible physical markings, gender, race, facial hair, wearing of glasses; natural physiography, such as skull measurements, teeth and skeletal injuries, thumbprint, fingerprint sets, handprints, retinal scans, ear lobe capillary patterns, hand geometry, DNA patterns; bio-dynamics, the manner in which one's signature is written, statistically analysed voice characteristics, keystroke dynamics, particularly login-ID and password; social behaviour (supported by video-film), habituated body signals, general voice characteristics, style of speech, visible handicaps; imposed physical characteristics, dog tags, collars, bracelets and anklets, bar codes and other kinds of brands, embedded microchips and transponders.

The law will need to respond to this dangerous trend.

\section{New Wrongs and Rights}

Advances in technology are predictably accompanied by new forms of mischief. Today it is classical evil; tomorrow it is another evil facilitated by the digital world we now inhabit.

The law is not always the most effective or appropriate instrument to deploy against these novel depredations. Technology itself frequently offers superior solutions. In the case of the Internet, for example, a variety of measures exist to protect personal data online. These include the encryption, economization, and erasure of personal data. While new-fangled wrongs will continue to emerge, some transgressions are simply digital versions of old ones. Among the more obvious novel threats, there is a number which teases the law's capacity to respond to new offences. These include complex problems arising largely from the ease with which data, software, or music may be copied. The pillars upon which intellectual property law was constructed have been shaken. This incorporates the law of patents and trademarks, especially in respect of domain names. Defective software gives rise to potential contractual and tortious claims for compensation. The storage of data on mobile telephones and other devices relentlessly tests the law's ability to protect the innocent against the 'theft' of information. New threats emerge almost daily. Employers have been warned of the relative ease with which their workers may appropriate data by "podslurping", a simple operation that consists in the unauthorized downloading of data from a computer to a small device such as an iPod, MP3 player, or flash drive. 


\section{Internet Iniquity}

Malevolent websites are multiplying by the day. A study by Google found 450,000 booby-trapped pages out of a sample of 4.5 million pages. A further 700,000 looked likely to be dangerous. Most of the websites exploit weaknesses in Microsoft's Internet Explorer browser ... increasingly common are sites that steal private details or turn your computer into a «bot» one which is remotely controlled by someone else. Bots can be used to penetrate email addresses, send spam and conduct attacks on corporate websites. Then there are the "Denial of Service" (DoS) attacks, which use

armies of «bots» or "zombies" to flood company websites with fake data requests. The words conjure up images from Night of the Living Dead and the reality is the online equivalent of consuming a living person's flesh, as hundreds of thousands of 'zombies' attack a website until they've taken it offline which can disable it for days and facilitate the criminal acts. Cybercrime poses new challenges for criminal justice, criminal law, and law enforcement both nationally and internationally.

Innovative online criminals generate major headaches for police, prosecutors, and Courts. This new terrain incorporates cyber crimes against the person and cybercrimes against property (such as hacking, viruses, causing damage to data), cyber-fraud, identity theft, and cyber-terrorism. Cyberspace provides organized crime with more sophisticated and potentially more secure methods for supporting and developing networks for a range of criminal activities, including drug and arms trafficking, money laundering, and custom-smuggling. Usually, the attacks are accompanied by demands for money. Gambling and porn sites were among the first to get hit: reluctant to seek police help, they paid the ransom.

Of course, there are defences against hackers, and you'd be mad not to install anti-virus, anti-spyware and anti-spam software on your personal computer.

The future looks even more terrifying. The online auction sites that criminals use to sell user details are just the beginning. One of the web's current favourites - « mashup » sites that put together different databases - being turned to illicit use.

\section{Protecting Software}

Complex legal issues surround the question of patenting software. A patent is the grant of an exclusive right to exploit or develop an invention.

With the introduction of various forms of computer programs and other types of software, the law will continue to fight challenges and problems as to whether there is sufficient novelty in the software to justify patentability. In general, the law takes the view that computer programs are not patentable unless they constitute a genuine invention with industrial application. 
There is, on the other hand, a greater readiness to provide copyright protection to software, web pages, and even email messages since their owners have, as the name implies, the right to copy the material and, by extension, the right to prevent others from doing so. Software piracy has grown into a significant menace to major software producers such as Microsoft, but the issue is extremely controversial since, though it is clear that certain countries (China, Vietnam) engage in the wholesale copying of software, it is argued that the huge losses (up to twelve (12) billion US dollars) that companies such as Microsoft claim they suffer is illusory because many of those who purchase pirated software are unable to afford legitimate versions. Moreover, it is contended by opponents of the copyright for computer programs such as the Free Software Foundation that «free software » is a matter of liberty, not price. To understand the concept, you should think of «free » as in « free speech », not as in «free product». Free software is a matter of the user's freedom to run, copy, distribute, study, change and improve the software. But, as mentioned above, some wrongs have simply undergone a digital rebirth. For example, the tort of defamation has found a congenial new habitat in cyberspace. The law in most jurisdictions protects the reputation of persons through the tort of defamation or its equivalent. It will be recalled that while there are variations within law jurisdictions, the law generally imposes liability where the defendant intentionally or negligently publishes a false, unprivileged statement of fact that harms the plaintiff reputation.

Civil law systems, instead of recognizing a separate head tort of defamation protect reputation under the wing of rights of the personality. In cyberspace, however, national borders tend to disintegrate, and such distinctions lose much of their importance.

The advent of email, chat rooms, bulletin boards, newsgroups, and blogs provide fertile ground for defamatory statement online. Since the law normally requires publication to only one person other than the victim, an email message or posting on a newsgroup will suffice to found liability. But it is not merely the author of the libel who may be liable. In an important, if somewhat unclear, decision, a New York Court held an Internet service provider responsible for defamatory statements that appeared on its bulletin boards. The basis of the judgment was that the provider was a «publisher » principally because it had exercised editorial control over the content of its bulletin boards. In pursuit of this objective, it had posted « content guidelines » to its users, and it employed a software screening program to screen postings for offensive language. New York Court in an earlier decision, had decided that another service provider, CompuServe, was not liable for defamatory statements that appeared on one of its online forums. The judgment was based on the fact that the defendants were merely distributors rather than publishers. It was the functional equivalent of a lending library. Under these circumstances, « free speech » should prevail. 


\section{Future Courts and Lawyers}

It is not merely the law but its institutions and practitioners whose future will be profoundly affected by the developments in information technology. It is improbable that judges will be replaced by computers, but the administration of justice in many advanced societies has already undergone significant changes and will continue to do so. The Courts of several jurisdictions already benefit from access to legal materials that previously would have consumed long hours of research. Virtual law libraries with sophisticated search facilities enable judges, jurists, lawyers, legal academics, and ordinary members of society to obtain rapid access to statutes, cases, and other sources of law. This will be helpful to less affluent countries with limited legal resources.

Increasingly, judgments of the Courts are posted on the Internet almost immediately after they have been handed down. There are already several excellent online legal databases such as findlaw.com. The electronic transcription of court proceedings, the management of cases, and standardization of electronic

documents will continue to enhance the judicial process, streamlining and reducing notorious delays. The sight of a judge laboriously taking written notes is already disappearing, but voice-recognition technology will obviate the need for note-taking of any kind. Both evidence and legal sources can effortlessly be retrieved electronically. A more radical development might be the establishment of virtual courts in which the parties conduct proceedings without the need for corporeal proximity, thereby decreasing cost and delay.

Many of these advances are likely to generate significant advantages for the ordinary individual seeking access to justice.

Once legal information and services become more widely available, it ought to follow that the grandiose ambitions of the law and legal system will be more effectively accomplished. The role of lawyers and the administration of justice will no longer be dominated by print and paper in tomorrow's legal model. Instead, legal systems of the information society will evolve rapidly under the considerable influence of ever more powerful information technologies. We will no longer suffer from the excessive quantity and complexity of legal material.

There will be mechanisms in place to give everyone fair warning of the existence of new law. Legal risks will be managed in advance of problems occurring and so dispute pre-emption rather than dispute resolution will be the order of the day. Our law will thus become far more fully integrated with our domestic, social and business lives. Who would not welcome this sanguine prophecy?

\section{The Role of Law in a Movable World}


The 21st century yields a few reasons to be delightful. Our world continues to be blighted by war, genocide, poverty, disease, corruption, and greed. More than one-sixth of its inhabitants - over a billion people - live on less than $\$ 1$ a day. Over 800 million go to bed hungry every night, representing $14 \%$ of the world's population. The United Nations estimates that hunger claims the lives of about 25,000 people every day. The relationship between poverty and disease is unambiguous. In respect of HIV/AIDS, for example, $95 \%$ of cases occur in developing countries. Two-thirds of the forty (40) million people infected with HIV live in sub-Saharan Africa. Amid these gloomy statistics, occasional shafts of light appear to justify optimism. There has been some progress in diminishing at least some of the inequality and injustice that afflict individuals and groups in many parts of the world. And this has been, in no

small measure, an important achievement of the law. It is easy, and always fashionable, to disparage the law, and especially jurists, for neglecting - or even aggravating - the world's misery.

Yet such cynicism is increasingly unfounded in the light of the Progress in the legal recognition and protection of human rights. The adoption by the United Nations, in the grim shadow of the Holocaust, of the Universal Declaration of Human Rights in 1948, and the International Covenants on Civil and Political Rights, and Economic, Social and Cultural Rights in 1976, demonstrates, even to the most sceptical observer, a commitment by the international community to the universal conception and protection of human rights. This so-called International Bill of Rights, with its inevitably protean and ideological character, reflects an extraordinary measure of cross-cultural consensus among nations. The idea of human rights has passed through three generations: The first generation consisted of mostly « negative » civil and political rights which don't interfere within certain prohibited ways, for example, my right to speak freely. The second generation consisted of « positive » rights when they express a claim to something such as education or health or legal representation. These secondgeneration rights assemble under the umbrella of economic, social, and cultural rights. The third generation of rights comprises primarily collective rights which are assembled in Article 28 of the Universal Declaration which declares that 'everyone is entitled to a social and international order in which the rights set forth in this Declaration can be fully realized'. These 'solidarity' rights include the right to social and economic development and to participate in and benefit from the natural resources of the earth and space, scientific and technical information (which are especially important to the Third World), the right to a healthy environment, peace, and humanitarian disaster relief.

It is sometimes contended that unwarranted primacy is given to positive rights at the expense of negative rights but, the reality is that both sets of rights are equally important.

Democratic governments that respect « free speech » are more likely to address the needs of its poor individuals. And, on the other hand, in societies where 
economic and social rights are protected, democracy has an enhanced prospect of success since people are not preoccupied with concerns about their next meal. Misgivings surrounding the concept of human rights are not new. Qualms are expressed by those who perceive the expanding recognition of human rights as undermining the "war on terror». Still, others find many of the rights expressed in declarations to be incoherent in such vague and general terms, and weakened by inevitable exclusions and exemptions, that often they appear to take away with one hand what they give with the other. In impoverished countries, modern conceptions of human rights are at times regarded with suspicion as Western or Eurocentric, failing to address the problems of starvation, poverty, and suffering that afflict many of their people. Indeed, it is asserted that they merely shore up the prevailing distribution of wealth and power.

These, and many other, doubts about the development of human rights are not to be lightly dismissed. Nor should we be under any illusion that international, or indeed domestic, declarations or the agencies that exist to implement them are adequate. They provide the contours of a strategy for improved protection. The role of the numerous non-governmental organizations (NGOs), independent human rights commissions, pressure groups, and courageous individuals is of paramount importance. The growing body of law on the subject does promote a degree of optimism about the future well-being of humanity. In view of our planet's ecological despoliation and even potential nuclear immolation, it is necessary, if not essential, to conceive of rights as a weapon by which to safeguard the interests of all living things against harm and to promote the circumstances under which they are able to flourish.

A fundamental shift in our social and economic systems and structures may be the only way in which to secure a sustainable future for our world and its inhabitants. The universal recognition of human rights seems to be an indispensable element in this process.

The future will doubtless challenge the capacity of the law not only to control domestic threats to security but also to negotiate a rational approach to the menace of international terrorism. Public international law and the United Nations Charter will continue to offer the optimal touchstone by which to determine what constitutes tolerable conduct in respect of both war and peace. 'Humanitarian intervention' has in recent years become a significant feature of the international scene. There is increasing support for action to prevent or avoid the horrors of gruesome flashpoints around the world.

Moreover, in a world in which the law must confront an insidious enemy within, the foundations of international law are severely tested. This war is waged not between States, but by a clandestine international terrorist network with pernicious ambitions. 
It is easy, to exaggerate the significance of the law. Yet history teaches that the law is an essential force in facilitating human progress. Without law, as Thomas Hobbes declared: «there is no place for industry because the fruit thereof is uncertain; and consequently no culture of the Earth, no Navigation, nor use of the commodities that may be imported by sea; no commodious building, no instruments of moving and removing such things as require much force; no Knowledge of the face of the Earth, no account of Time, no Arts, no Letters, no Society; and which is worst of all, continual fear and danger of violent death; and the life of people, solitary, poor, nasty, brutish, and short ».

If we are to survive the calamities that await us, if civilized values and justice are to prevail and endure, the law is surely indispensable.

NB : References in my book «LAW », ed. Sadat Faculty of Law, 2019/2020. 